\title{
Literasi Finansial Keluarga Pekerja Migran Indonesia Ditinjau Dari Pengelolaan Remitan
}

\author{
Bayu Adi Laksono \\ Sekolah Tinggi Keguruan dan Ilmu Pendidikan (STKIP) Modern Ngawi \\ Email: bayuadi.laksono@yahoo.co.id
}

\begin{abstract}
The purpose of this study was to examine the financial literacy of migrant worker families in terms of remittance management. This study was conducted in seven hamlets of Payaman Solokuro Village, Lamongan Regency. Using cluster random sampling techniques in determining the research sample and using the Harry King Nomogram in determining the number of samples, as many as 95 persons. Data analysis uses ANOVA (Analysis of Variant) technique. The results showed that $63.2 \%$ of migrant workers' families received remittances of 1-3 million each sending period, and $81.1 \%$ received remittances once a month. The literacy rate of migrant workers' families from the perspective of remittance receipts intensity is in medium level, however migrant workers' families who receive remittances in period of once in three months tend a high level of literacy. Families of migrant workers who receive remittances of more than three million each sending period are higher in financial literacy than others. The results of data analysis show that the financial literacy of migrant workers' families do not have a significant difference in terms of the remittance receipts intensity, and the financial literacy of migrant workers' families in terms of remittance receiptsquantitydo not have a significant difference. The results of this study indicate that migrant workers' families can increase their financial literacy through financial training and have careful considerationsin making economic decisions.
\end{abstract}

\section{Keywords: Financial Literacy, Family, Migrant Worker}

\begin{abstract}
Abstrak: Tujuan penelitian ini untuk mengkaji literasi finansial keluarga pekerja migran ditinjau dari pengelolaan remitan, baik dari intensitas maupun kuantitas. Penelitian ini dilakukan di tujuh dusun dari Desa Payaman Solokuro Kabupaten Lamongan. Menggunakan teknis cluster random sampling dalam menetukan sampel penelitian serta menggunakan Nomogram Harry King dalam menentukan besaran sampelnya, yakni sebanyak 95 orang. Analisis data menggunakan teknik ANOVA (Analysis of Varian). Hasil penelitian menunjukkan bahwa 63,2\% keluarga pekerja migran mendapat remitan sebanyak 1-3 Juta setiap periode pengirimannya, serta $81,1 \%$ menerima remitan sebulan sekali. Tingkat literasi keluarga pekerja migran ditinjau dari sudut pandang intensitas penerimaan remitan berada pada tingkat sedang, namun keluarga pekerja migran yang menerima remitan pada periode tiga bulan sekali cenderung memiliki tingkat literasi yang tinggi. Keluarga pekerja migran yang menerima kiriman remitan lebih dari tiga juta setiap periode pengirimannya cenderung memiliki tingkat literasi finansial yang lebih tinggi diantara yang lainnya. Hasil analisis data menunjukkan bahwa literasi finansial keluarga pekerja migran tidak memiliki perbedaaan yang signifikan ditinjau dari intensitas penerimaan uang remitan, serta literasi finansial keluarga pekerja migran ditinjau dari kuantitas penerimaan uang remitan tidak memiliki perbedaan yang signifikan. Hasil penelitian ini menunjukkan bahwa keluarga pekerja migran dapat meningkatkan literasi finansialnya melalui pelatihan pengelolaan keuangan serta memiliki pertimbangan yang matang dalam mengambil keputusan ekonomi.
\end{abstract}

Kata Kunci: Literasi, Finansial, Keluarga, Pekerja Migran

\section{PENDAHULUAN}

Secara umum remitan dimaknai sebagai bagian dari pendapatan pekerja migran yang dianggarkan untuk dikirim ke tempat asal pekerja migran (Wiyono, 1994). Pemaknaan remitan tersebut mengalami perluasan makna, definisi remitan bukan hanya terbatas pada sektor keuangan atau ekonomi, melainkan pada hal-hal yang lebih abstrak seperti pemikiran baru dan kecakapan (Connell, Biplab Dasgupta, Roy Laishley, \& 
Michael Lipton, 1976). Dalam konteks remitan ekonomi (uang kiriman), hal tersebut akan menjadi hal yang riskan, karena sukses tidaknya pekerja migran bekerja selama di luar negeri ditentukan pada pengelolaan remitan (uang kiriman). Hasil kajian menunjukkan bahwa pengelolaan keuangan/ekonomi dari keluarga pekerja migran merupakan hal sangat penting, mengingat permasalahan ekonomi menjadi salah satu penyebab tingginya angka perceraian pada kalangan pekerja migran (Miladiyanto, 2016).

Upaya menjaga keharmonisan keluarga pekerja migran diperlukan dalam rangka peningkatan ketahanan keluarga. Ketahanan keluarga menyangkut kemampuan keluarga dalam mengelola masalah yang dihadapinya berdasarkan sumberdaya yang dimiliki untuk memenuhi kebutuhan keluarganya. Semakin tinggi tingkat ketahanan keluarga, semakin baik pula suasana dalam keluarga (Mawarpury \& Mirza, 2017). Suasana kondusif dalam keluarga tentunya membawa dampak positif pada hubungan masing-masing anggota keluarga. Mengingat pentingnya pengelolaan keuangan serta dampak yang diberikan pada keadaan keluarga pekerja migran, penelitian ini bertujuan untuk mengkaji literasi finansial keluarga pekerja migran ditinjau dari pengelolaan remitan. Pengelolaan remitan dalam penelitian ini adalah intensitas penerimaan uang oleh keluarga pekerja migran, serta kuantitas penerimaan uang oleh keluarga pekerja migran yang dikirimkan pekerja migran.

\section{METODE}

Penelitian dilakukan di Desa Payaman Solokuro Kabupaten Lamongan. Desa tersebut dipilih sebagai tempat penelitian dikarenakan banyaknya pekerja migran di desa tersebut. Setting penelitian berada di tujuh dusun, dengan jumlah masing-masing sampel penelitian berdasarkan persentase jumlah pekerja migran pada masing-masing dusun. Teknik penentuan sampel menggunakan cluster random sampling, yaitu sampel secara acak dipilih berdasarkan tempat mereka tinggal. Besaran sampel menggunakan Nomogram Harry King dengan derajat kesalahan sebesar 9\% dengan jumlah akhir sebanyak 95 orang. Analisis data menggunakan teknik ANOVA (Analysis of Varian). Uji ANOVA dilakukan pada dua aspek yakni aspek intensitas penerimaan uang (sebulan sekali, tiga bulan sekali, enam bulan sekali, serta tidak menentu). Aspek yang kedua yang kuantitas penerimaan uang (kurang dari satu juta, antara satu sampai tiga juta, dan lebih dari tiga juta).

\section{HASIL}

\section{Intensitas dan Kuantitas Pengiriman Remitan}

Pada bagian ini dijelaskan mengenai frekuensi pengiriman remitan (uang) serta jumlah sekali pengiriman pada periode tertentu dari pekerja migran ke keluarga di Indonesia.

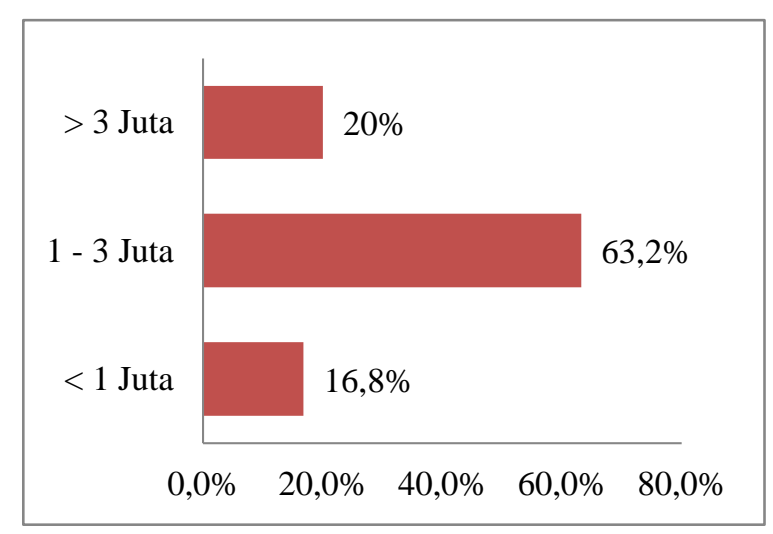

Gambar 1. Diagram Kuantitas Pengiriman Remitan 
Berdasarkan gambar 1 dinyatakan bahwa pekerja migran yang mengirimkan remitan kurang dari Rp. 1.000.000,00 sebanyak $16,8 \%$, sedangkan yang mengirimkan antara Rp. 1.000.000,00 sampai dengan Rp. 3.000.000,00 sebanyak $63,2 \%$, dan sebanyak $20 \%$ dari pekerja migran tersebut mengirimkan lebih dari Rp. 3.000.000,00 ke keluarganya yang berada di Indonesia.

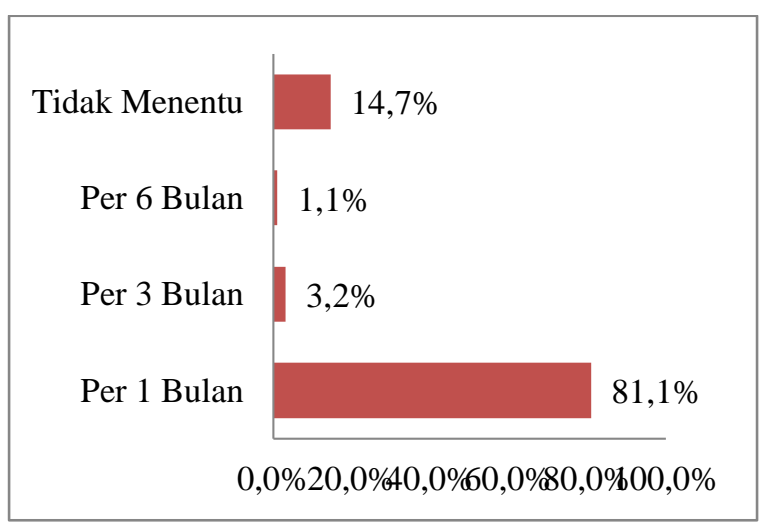

Gambar 2. Diagram Intensitas Pengiriman Remitan

Berdasarkan gambar 2 dinyatakan bahwa pekerja migran di luar negeri menyalurkan remitannya sebulan sekali sebanyak $81,1 \%$, kemudian sebanyak $3,2 \%$ menyalurkan remitannya setiap tiga bulan sekali, sebanyak $1,1 \%$ menyalurkan remitannya setiap enam bulan sekali, dan sisanya sebanyak $14,7 \%$ menyalurkan remitannya tidak mempunyai periode tertentu. Kajian lebih dalam para pekerja migran yang memilih menyalurkan remitannya tanpa periode tertertu bergantung pada permintaan dan kebutuhan keluarga yang berada di Indonesia.

\section{Tingkat Literasi Finansial Ditinjau Dari Intensitas Penerimaan Uang}

Pada bagian ini peneliti mengkaji mengenai tingkat literasi finansial keluarga pekerja migran ditinjau dari intensitas penerimaan uang (remitan) dari keluarganya yang bekerja di luar negeri. Tahapan yang pertama dalam mengkaji bagian ini adalah melakukan uji normalitas data. Uji normalitas data merupakan salah satu uji yang dilakukan dalam proses uji analisis varian. Uji normalitas data berfungsi sebagai syarat uji analysis of varian (one way anova).

Tabel 1. Uji Normalitas Literasi Finansial

Berdasar Intensitas Penerimaan Uang

\begin{tabular}{lccccccc}
\hline \multirow{2}{*}{$\begin{array}{c}\text { Seringnya } \\
\text { Mengirim Uang }\end{array}$} & \multicolumn{3}{c}{$\begin{array}{c}\text { Kolmogorov- } \\
\text { Smirnov }\end{array}$} & \multicolumn{3}{c}{ Shapiro-Wilk } \\
\cline { 2 - 8 } & Stat & df & Sig. & Stat & df & Sig. \\
\hline Sebulan Sekali &, 089 & 77 &, $200^{*}$ &, 984 & 77 &, 441 \\
3 Bulan Sekali &, 292 & 3 &. &, 923 & 3 &, 463 \\
Tidak Menentu &, 165 & 14 &, $200^{*}$ &, 955 & 14 &, 642 \\
\hline
\end{tabular}

Hasil uji normalitas menggunakan shapiro-wilk menunjukkan nilai signifikansi (sig.) >0,05. Hasil tersebut mengungkapkan bahwa data dinyatakan normal, dengan catatan mengabaikan opsi enam bulan sekali karena hanya terdiri dari satu pemilih, sehingga tidak masuk dalam hitungan grup. Opsi lainnya selain opsi enam bulan sekali dapat dianalisis karena dipilih lebih dari satu keluarga pekerja migran.

Tahapan selanjutnya setelah uji normalitas data adalah uji homogenitas. Uji homogenitas merupakan syarat yang harus dipenuhi agar uji anova dapat dilakukan. Berikut adalah tahapan uji homogenitas data literasi finansial berdasar intensitas penerimaan uang.

Tabel 2. Uji Homogenitas Literasi Finansial Berdasar Intensitas Penerimaan

\begin{tabular}{llll}
\hline Levene Statistic & df1 & df2 & Sig. \\
\hline, 630 & 2 & 91 &, 535 \\
\hline
\end{tabular}

Berdasarkan hasil uji homogenitas diperoleh nilai signifikansi (Sig) sebesar 0,535. Nilai signifikansi $0,535>0,05$ maka dapat disimpulkan bahwa varian intensitas penerimaan uang (remitan) yang 
dibandingkan tersebut adalah sama atau homogen, sehingga asumsi homogenitas dalam uji anova terpenuhi. Tahap selanjutnya sebelum uji anova, peneliti memberikan data gambaran mengenai tingkat literasi finansial keluarga pekerja migran ditinjau dari intensitas penerimaan uang (remitan) dari keluarganya yang bekerja di luar negeri.

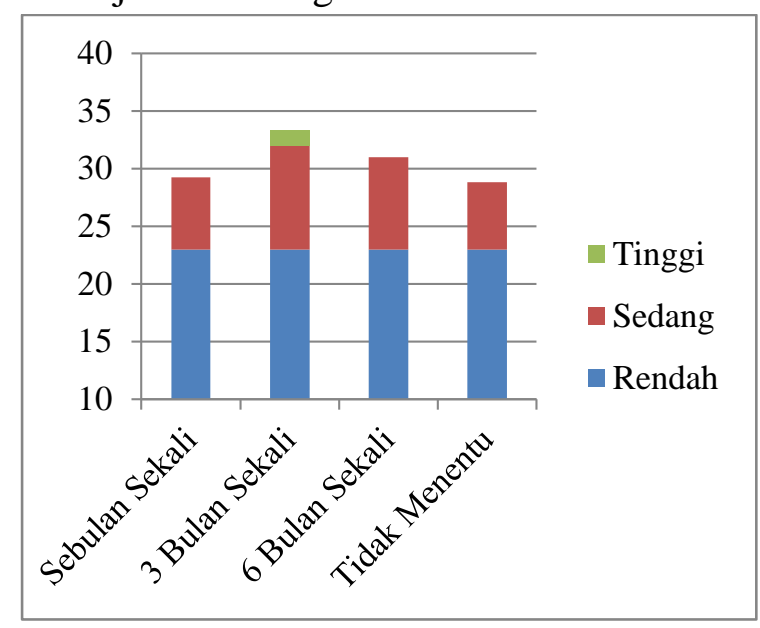

Gambar 3. Tingkat Literasi Finansial Berdasar Intensitas Penerimaan Uang

Gambaran rata-rata tingkat literasi finansial keluarga pekerja migran ditinjau dari intensitas penerimaan uang (remitan) dari keluarganya yang bekerja di luar negeri yakni keluarga pekerja migran yang menerima uang (remitan) setiap sebulan sekali rata-rata memiliki tingkat literasi finansial sebesar 29,2. Keluarga pekerja migran yang menerima uang (remitan) setiap tiga bulan sekali rata-rata memiliki tingkat literasi finansial sebesar 33,3. Keluarga pekerja migran yang menerima uang (remitan) setiap enam bulan sekali memiliki tingkat literasi finansial sebesar 31. Keluarga pekerja migran yang menerima uang (remitan) dengan periode yang tidak menentu memiliki rata-rata tingkat literasi finansial sebesar 28,9.

Tahapan selanjutnya yang dilakukan setelah uji normalitas dan homogenitas terpenuhi adalah uji anova. Uji anova bertujuan untuk mengetahui apakah terdapat perbedaan yang signifikan tingkat literasi finansial keluarga pekerja migran yang ditinjau dari intensitas penerimaan uang (remitan). Intensitas penerimaan uang (remitan) keluarga pekerja migran terdiri dari sebulan sekali, tiga bulan sekali, enam bulan sekali, dan pengiriman yang tidak menentu.

Tabel 3. Uji Anova Literasi Finansial Ditinjau dari Intensitas Penerimaan Uang

\begin{tabular}{lccccc}
\hline & $\begin{array}{c}\text { Sum of } \\
\text { Squares }\end{array}$ & df & $\begin{array}{c}\text { Mean } \\
\text { Square }\end{array}$ & F & Sig. \\
\hline $\begin{array}{l}\text { Between } \\
\text { Groups }\end{array}$ & 55,491 & 3 & 18,497 & 1,609 &, 193 \\
$\begin{array}{l}\text { Within } \\
\text { Groups }\end{array}$ & 1045,835 & 91 & 11,493 & & \\
Total & 1101,326 & 94 & & & \\
\hline
\end{tabular}

Berdasarkan hasil analisis melalui uji anova diketahui nilai signifikansi (sig.) sebesar 0,193 >0,05. Hasil tersebut menunjukkan atau dapat disimpulkan bahwa tidak terdapat perbedaan yang signifikan tingkat literasi finansial keluarga pekerja migran yang ditinjau dari intensitas penerimaan uang (remitan).

\section{Tingkat Literasi Finansial Ditinjau Dari Kuantitas Penerimaan Uang \\ Pada bagian ini dikaji mengenai} tingkat literasi finansial keluarga pekerja migran yang ditinjau melalui jumlah penerimaan uang dalam sekali periode. Sebelum tahap uji analisis data, peneliti melakukan uji normalitas data menggunakan kolmogorov-smirnov dan shapiro-wilk. Uji normalitas data digunakan sebagai syarat uji anova yang digunakan untuk mengukur rata-rata perbedaan masing-masing variabel yang ada. 
Tabel 4. Uji Normalitas Literasi Finansial dari Kuantitas Penerimaan

\begin{tabular}{lcccccc}
\hline Jumlah & \multicolumn{3}{c}{ Kolmogorov-Smirnov } & \multicolumn{4}{c}{ Shapiro-Wilk } \\
\cline { 2 - 7 } $\begin{array}{l}\text { Sekali } \\
\text { Kirim }\end{array}$ & Stat & df & Sig. & Stat & df & Sig. \\
\hline$<1$ juta &, 182 & 16 & $\mathbf{, 1 6 5}$ &, 934 & 16 & $\mathbf{, 2 7 8}$ \\
$1-3$ juta &, 089 & 60 & $\mathbf{, 2 0 0}^{*}$ &, 976 & 60 & $\mathbf{, 2 7 0}$ \\
$>3$ juta &, 148 & 19 & $\mathbf{, 2 0 0}^{*}$ &, 913 & 19 & $\mathbf{, 0 8 5}$ \\
\hline
\end{tabular}

Hasil uji normalitas menggunakan kolmogorov-smirnov dan shapiro-wilk menunjukkan nilai signifikansi (Sig.) > 0,05. Hasil tersebut menunjukkan bahwa data dinyatakan normal. Tahapan selanjutnya setelah uji normalitas data adalah uji homogenitas. Uji homogenitas merupakan salah satu syarat agar uji anova dapat dilakukan.

Tabel 5. Uji Homogenitas Literasi Finansial dari Kuantitas Penerimaan

\begin{tabular}{llll}
\hline Levene Statistic & df1 & df2 & Sig. \\
\hline 2,062 & 2 & 92 &, 133 \\
\hline
\end{tabular}

Berdasarkan hasil uji homogenitas diperoleh nilai signifikansi (Sig) sebesar 0,133 . Hasil tersebut menunjukkan bahwa nilai signifikansi $0,133>0,05$ maka dapat disimpulkan bahwa jumlah penerimaan uang (remitan) yang dibandingkan tersebut homogen. Hasil tersebut juga menyatakan bahwa asumsi homogenitas dalam uji one way anova terpenuhi. Tahap selanjutnya sebelum melakukan uji anova, peneliti menggambarkan data mengenai tingkat literasi finansial yang dikaji berdasarkan jumlah penerimaan uang (remitan) setiap periode.

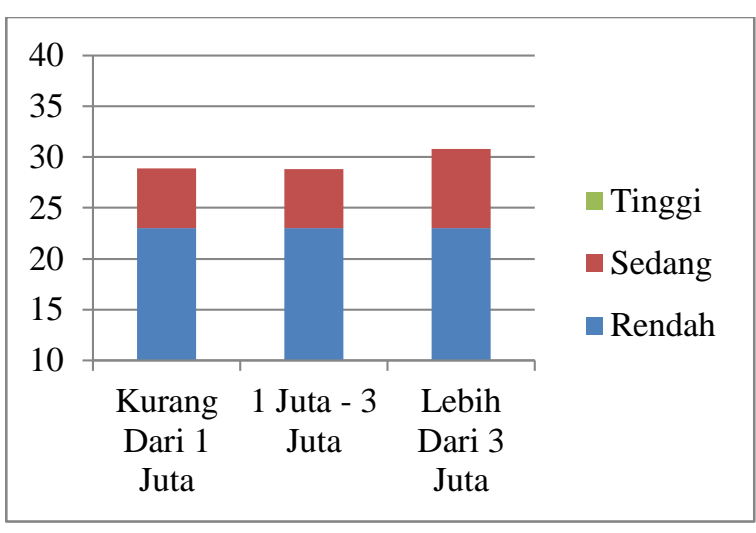

Gambar 4. Rata-rata Literasi Finansial Ditinjau dari Kuantitas Penerimaan

Gambaran rata-rata tingkat literasi finansial keluarga pekerja migran ditinjau dari jumlah penerimaan kiriman uang (remitan) dalam satu kali periode yakni keluarga pekerja migran yang menerima kiriman uang (remitan) kurang dari satu juta rupiah memiliki rata-rata tingkat literasi finansial sebanyak 28,9. Keluarga pekerja migran yang menerima kiriman uang (remitan) antara satu juta hingga tiga juta rupiah memiliki rata-rata tingkat literasi finansial sebanyak 28,8. Keluarga pekerja migran yang menerima kiriman uang (remitan) lebih dari tiga juta rupiah memiliki rata-rata tingkat literasi finansial sebanyak 30,8.

Tahapan selanjutnya setelah asumsi normalitas dan homogenitas terpenuhi adalah tahap uji anova. Uji anova bertujuan untuk melihat apakah terdapat perbedaan tingkat literasi finansial keluarga pekerja migran yang ditinjau dari jumlah penerimaan kiriman uang (remitan) dalam satu kali periode pengiriman.

Tabel 6. Uji Anova Literasi Finansial Ditinjau dari Kuantitas Penerimaan

\begin{tabular}{llllll}
\hline & \multicolumn{1}{c}{$\begin{array}{c}\text { Sum of } \\
\text { Squares }\end{array}$} & df & $\begin{array}{c}\text { Mean } \\
\text { Square }\end{array}$ & F & Sig. \\
\hline $\begin{array}{l}\text { Between } \\
\text { Groups }\end{array}$ & 61,666 & 2 & 30,833 & 2,728 & $\mathbf{, 0 7 1}$ \\
$\begin{array}{l}\text { Within } \\
\text { Groups }\end{array}$ & 1039,660 & 92 & 11,301 & & \\
Total & 1101,326 & 94 & & & \\
\hline
\end{tabular}


Berdasarkan hasil analisis melalui uji anova diketahui nilai signifikansi (sig.) sebesar $0,071>0,05$. Hasil tersebut menunjukkan atau dapat disimpulkan bahwa tidak terdapat perbedaan yang signifikan tingkat literasi finansial keluarga pekerja migran yang ditinjau dari banyaknya menerima uang (remitan) setiap periode pengiriman.

\section{PEMBAHASAN}

\section{Literasi Finansial Keluarga Pekerja Migran Ditinjau Dari Intensitas Penerimaan Remitan}

Hasil dari kajian penelitian ini menyatakan bahwa tidak terdapat perbedaan yang signifikan tingkat literasi finansial yang ditinjau dari intensitas penerimaan kiriman uang (remitan) dari pekerja migran yang berada di luar negeri kepada keluarga pekerja migran di Indonesia. Uji ini dilakukan untuk mengetahui perbedaan tingkat literasi finansial keluarga pekerja migran yang menerima kiriman uang setiap sebulan sekali, tiga bulan sekali, enam bulan sekali, serta penerimaan uang yang tidak menentu tergantung kebutuhan. Pada uji ini peneliti mengabaikan opsi enam bulan sekali, karena hanya dipilih oleh satu responden sehingga tidak bisa masuk dalam hitungan kelompok. Masing-masing pilihan intensitas penerimaan memiliki rata-rata tingkat literasi yang berbeda meskipun perbedaannya tidak terlalu signifikan. Keluarga pekerja migran yang menerima kiriman uang (remitan) setiap sebulan sekali memiliki rata-rata tingkat literasi finansial dalam kategori sedang dengan skor sebanyak 29,2. Keluarga pekerja migran yang menerima kiriman uang (remitan) setiap tiga bulan sekali memiliki rata-rata tingkat literasi finansial dalam kategori tinggi dengan skor sebanyak 33,3. Keluarga pekerja migran yang menerima kiriman uang (remitan) setiap enam bulan sekali memiliki tingkat literasi finansial sebesar 31 dan masuk pada kategori sedang. Keluarga pekerja migran yang menerima kiriman uang (remitan) dengan periode tidak menentu memiliki rata-rata tingkat literasi finansial yang sedang dengan skor 28,9.

Keluarga pekerja migran dengan tingkat literasi finansial yang paling tinggi terdapat pada keluarga pekerja migran yang menerima kiriman uang (remitan) dengan periode tiga bulan sekali, sedangkan paling rendah adalah yang periode pengiriman uang (remitan) tidak menentu. Pengiriman uang (remitan) yang tidak menentu kemungkinan besar sangat dipengaruhi oleh keputusan yang bersifat emosional. Tidak adanya periode pengiriman uang (remitan) yang jelas maka jika pengiriman terlalu sering dapat diindikasikan sebagai tindakan yang konsumtif, namun jika terlalu jarang akan mengabaikan kebutuhan-kebutuhan yang penting. Dampak pengiriman uang (remitan) kepada keluarga pekerja migran yang tidak memiliki periode tertentu cenderung terindikasi memiliki kontrol diri yang rendah. Kontrol diri yang rendah merupakan gabungan dari pemikiran, perilaku, dan keputusan yang diawali dengan kemampuan seseorang untuk merangkai informasi-informasi yang ada, kemudian bertindak berdasarkan informasi yang telah dirangkai dan kemudian mengambil keputusan dengan apa yang diyakininya (Averill, 1973). Kurangnya kontrol diri mendorong adanya tindakan ekonomi yang tidak terkontrol, salah satunya ada perilaku ikut-ikutan (Utami \& Sumaryono, 2008). Kontrol diri yang rendah juga berpengaruh positif terhadap perilaku menabung, semakin baik kontrol 
diri semakin baik pula perilaku menabung (Ardiana, 2016). Berdasarkan kajian pustaka, perilaku menabung merupakan salah satu indikator dari tingkat literasi finansial. Lebih lanjut keluarga pekerja migran yang menerima kiriman uang (remitan) yang tidak memiliki periode pengiriman tertentu terindikasi memiliki literasi finansial yang rendah. Rendahnya tingkat literasi finansial memiliki korelasi dengan problema pinjaman. Hal tersebut menyatakan bahwa keluarga pekerja migran yang tidak cukup memiliki pengetahuan dan keterampilan mengenai keuangan dimungkinkan akan terjerumus pada kasus pinjaman (Lusardi \& Tufano, 2015).

\section{Literasi Finansial Keluarga Pekerja Migran Ditinjau Dari Kuantitas Penerimaan Remitan}

Hasil kajian dalam penelitian ini memaparkan bahwa tidak terdapat perbedaan yang signifikan tingkat literasi finansial ditinjau dari jumlah penerimaan uang (remitan) yang dikirimkan kepada keluarga pekerja migran. Uji ini dilakukan untuk mengetahui perbedaan tingkat literasi finansial kelompok keluarga pekerja migran yang menerima kiriman kurang dari satu juta rupiah, antara satu sampai tiga juta, serta kelompok keluarga pekerja migran yang menerima kiriman lebih dari tiga juta. Masing-masing kelompok memiliki perbedaan tingkat literasi finansial meskipun secara angka tidak signifikan. Keluarga pekerja migran yang menerima kiriman berjumlah kurang dari satu juta rupiah setiap kali kirim berada pada tingkat literasi finansial kategori sedang dengan skor 28,9. Keluarga pekerja migran yang menerima kiriman uang (remitan) antara satu sampai tiga juta rupiah setiap kali kirim masuk pada kategori literasi sedang dengan skor 28,8, sedangkan keluarga pekerja migran yang menerima kiriman uang (remitan) lebih dari tiga juta rupiah setiap kali kirim masuk pada kategori sedang dengan skor 30,8 .

Keluarga pekerja migran yang menerima uang (remitan) lebih dari tiga juta rupiah merupakan kelompok keluarga pekerja migran dengan rata-rata tingkat literasi finansial paling tinggi di antara kelompok keluarga pekerja migran lainnya. Keberhasilan pengelolaan keuangan bisa dicapai dengan memiliki lima tujuan keuangan keluarga antara lain pendapatan yang cukup, konsumsi yang tepat sasaran, kebahagiaan, pengaturan keuangan yang aman, dan mempersiapkan masa pensiun dan warisan (Garman \& Forgue, 1994). Pengatur keuangan rumah tangga memiliki peran strategis dalam mencapai lima tujuan tersebut, sehingga keputusan dalam membagi kiriman uang (remitan) dari pekerja migran ke dalam masing-masing pos anggaran harus sangat cermat. Pembagian masing-masing pos anggaran oleh pengatur keuangan rumah tangga menjadi lebih mudah karena dana yang tersedia sangat cukup, sebaliknya jika penerimaan uang (remitan) sangat terbatas, tentu pengatur keuangan menjadi lebih ketat dan cermat dalam mengatur keuangan. Hal tersebut didasarkan bahwa perencanaan keuangan adalah kunci strategis dalam pengaturan keuangan keluarga secara maksimal (Supramono \& Putlia, 2017).

\section{SIMPULAN}

Literasi finansial keluarga pekerja migran ditinjau dari intensitas penerimaan uang remitan tidak memiliki perbedaaan yang signifikan, baik antara keluarga pekerja migran yang mendapat kiriman 
sebulan sekali, tiga bulan sekali, enam bulan sekali, maupun yang mendapat kiriman tidak menentu tidak memiliki perbedaan yang signifikan. Namun, keluarga pekerja migran dengan kiriman uang dalam periode tiga bulan sekali cenderung memiliki literasi finansial yang lebih tinggi daripada yang lain, sedangkan keluarga pekerja migran yang menerima kiriman uang dengan periode kiriman tidak menentu cenderung memiliki tingkat literasi lebih rendah.

Literasi finansial keluarga pekerja migran ditinjau dari kuantitas penerimaan uang remitan tidak memiliki perbedaan yang signifikan, baik antara keluarga pekerja migran dengan kiriman kurang dari satu juta, antara satu sampai tiga juta, serta jumlah pengiriman lebih dari tiga juta setiap periode pengirimannya. Namun, keluarga pekerja migran yang menerima kiriman remitan lebih dari tiga juta setiap periode pengirimannya cenderung memiliki tingkat literasi finansial lebih tinggi dibandingkan lainnya.

\section{DAFTAR RUJUKAN}

Ardiana, M. (2016). Kontrol Diri, Pendidikan Pengelolaan Keuangan Keluarga, Pengetahuan Inklusi Keuangan Siswa Pengaruhnya terhadap Perilaku Menabung Siswa SMK Se Kota Kediri. Jurnal Ekonomi Pendidikan dan Kewirausahaan, 4(1), 59-75.

Averill, J. R. (1973). Personal control over aversive stimuli and its relationship to stress. Psychological bulletin, 80(4), 286.
Connell, J., Biplab Dasgupta, Roy Laishley, \& Michael Lipton. (1976). Migration from rural Areas. The Evidence from Village Studies. Delhi: Oxford University Press.

Garman, E. T., \& Forgue, R. E. (1994). Personal Finance. Boston: Houghton Mifflin Company.

Lusardi, A., \& Tufano, P. (2015). Debt literacy, financial experiences, and overindebtedness. Journal of Pension Economics \& Finance, 14(4), 332-368. https://doi.org/10.1017/S14747472 15000232

Mawarpury, M., \& Mirza, M. (2017). Resiliensi Dalam Keluarga: Perspektif Psikologi. Psikoislamedia : Jurnal Psikologi, 2(1), 96. https://doi.org/10.22373/psikoislam edia.v2i1.1829

Miladiyanto, S. (2016). Pengaruh Profesi Tenaga Kerja Indonesia (Tki) Terhadap Tingginya Perceraian Di Kabupaten Malang. Jurnal Moral Kemasyarakatan, 1(1), 51-66.

Supramono, S., \& Putlia, N. (2017).

Persepsi dan faktor psikologis dalam pengambilan keputusan hutang. Jurnal keuangan dan Perbankan, 14(1), 24-35. https://doi.org/10.26905/jkdp.v14i1 .947

Utami, F. A., \& Sumaryono. (2008). Pembelian Impulsif Ditinjau dari Kontrol Diri dan Jenis Kelamin Pada Remaja. Jurnal Psikologi Proyeksi, 3(1).

Wiyono, N. . (1994). Mobilitas Tenaga

Kerja dan Globalisasi. Warta Demografi, (3), 8-13. 